\title{
O ANALISTA, O TRADUTOR E O IMPOSSÍVEL Dulce DUQUE-ESTRADA
}

Este texto desenvolve a ideia de que, na transmissão da psicanálise, o tradutor é um coautor, simultaneamente alienado aos significantes do autor original e mergulhado no próprio inconsciente.

Palavras-chave: psicanálise; tradução; transmissão.

\section{THE ANALYST, THE TRANSLATOR AND THE IMPOSSIBLE}

This paper develops the idea that in the transmission of psychoanalysis, the translator is a coauthor, simultaneously alienated to the signifiers of the original author and immersed in his/her own unconscious.

Keywords: psychoanalysis; translation; transmission.

\section{DA TRADUÇÃO COMO AMORTECIMENTO Lenita M. Rimoli ESTEVES}

Este trabalho discute situações em que tradutores, intérpretes e mediadores são levados a suavizar os termos, o tom ou qualquer outro aspecto de uma mensagem para evitar resultados indesejados. Tais situações são geralmente caracterizadas por uma grande tensão e pela contraposição de interesses, posicionamentos e ideais. Tentando evitar maiores conflitos, o tradutor/mediador se afasta do modelo tradicional de tradução, caracterizado pela imparcialidade e neutralidade. Corroborando a opinião de outros autores, o trabalho defende a ideia de que esse tipo de situação conflituosa merece uma atenção especial dos Estudos da Tradução.

Palavras-chave: ética na tradução; situações de conflito; tradução como amortecimento.

\section{TRANSLATION AS BUFFERING}

This work investigates specific situations in which translators, interpreters and mediators are led to smooth the terms, the tone or any other aspect of a message to avoid undesired results. Such situations are characterized by great tension and by conflicting interests, opinions and ideals. The translator/mediator avoids awkward situations that may result in serious conflicts, moving away from traditional translation models, characterized by impartiality and neutrality. In line with the opinion of other authors, this work emphasizes the idea that such conflicting situations deserve special attention from translation studies.

Keywords: ethics in translation; conflicting situations; translation as buffering.

\section{BECKETT E A LÍNGUA DOS OUTROS - QUE OUTROS? Helena MARTINS}

Este trabalho pensa a tradução a partir da escrita de Samuel Beckett. Desviando-se da avenida aberta pelos importantes estudos acerca do Beckett autotradutor, toma um caminho menos frequentado e busca construir por um ângulo beckettiano uma reflexão preliminar acerca da relação entre tradução e alteridade. Lê-se em certa passagem de $O$ inominável, de valor metonímico para este estudo: "Sou de palavras, palavras dos outros, que outros...". Busca-se aqui pensar a questão da alteridade na tradução à luz da forma singular com que a escrita de Beckett nos permite reconhecer a "língua dos outros", a um tempo demiúrgica e inexplicável. Flagra-se aí a promessa remota de um 
caminho por onde escapar às aporias inerentes à percepção da linguagem como acontecimento inevitavelmente autorreferente.

Palavras-chave: Beckett; tradução; alteridade.

\section{BECKETT AND THE OTHERS' LANGUAGE - WHAT OTHERS?}

This work seeks to think translation in the light of Samuel Beckett's writings. Deviating from the avenue opened by the important studies on Beckett as a self-translator, it takes a path less traveled, and searches to develop a Beckettian reflection on the relationship between translation and alterity. In a passage of The Unnamable that has metonymic value for this study, we read: "I am in words, other's words, what others...". This article reflects on the question of alterity in translation by considering the unique way by which Beckett's writings allow us to think the "others' language", at one time demiurgic and insurmountable. A remote promise of a way to escape the aporias inherent to the perception of language as inevitably self-referential is there identified. Keywords: Beckett, translation, alterity.

\section{QUESTÕES ÉTICAS E POLÍTICAS EM TORNO DA TRADUÇÃO LITERÁRIA Maria Clara Castellões de OLIVEIRA}

Este trabalho objetiva apontar para o compromisso ético de tradutores profissionais e educadores e estudiosos da tradução atuantes no contexto brasileiro, e apresentar estratégias de ação para a conscientização de tradutores em formação a respeito do verdadeiro poder da tradução e do tradutor. Essas estratégias poderão contribuir para uma visibilidade maior da tradução e do tradutor por parte dos leitores não-profissionais e dos demais consumidores de traduções, que, ainda hoje, continuam sem ter ideia de que a tradução e os tradutores atuam como importantes formadores de identidades culturais.

Palavras-chave: compromisso ético; tradutores profissionais; professores de tradução; estudiosos da tradução; tradução literária.

\section{ETHICAL AND POLITICAL ISSUES CONCERNING LITERARY TRANSLATION}

This paper aims at calling attention to the ethical commitment of professional translators and translation educators and scholars who presently work in the Brazilian context, and at presenting strategies that can contribute to the awareness of translation students in relation to the actual power of translators and translation. These strategies may contribute to a greater visibility of translation and translators in relation to nonprofessional readers and other consumers of translations, who, in this day and age, continue to have no idea that translation and translators are important builders of cultural identities.

Keywords: ethical commitment; professional translators; translation educators; translation scholars; literary translation.

\section{CONHECIMENTO E VALOR: A ÉTICA EM PRIMEIRA PESSOA DE WITTGENSTEIN E SUAS IMPLICAÇÕES PARA OS ESTUDOS DA TRADUÇÃO Paulo OLIVEIRA}

No seu uso ordinário, o conceito de ética costuma ser associado a catálogos de normas e preceitos gerais para o convívio social e o exercício profissional. Uma outra acepção 
pode ser extraída da reflexão filosófica de Ludwig Wittgenstein, com implicações não desprezíveis para a teoria e a prática da tradução - no que tange não apenas à dimensão ética, mas também aos próprios fundamentos da significação.

Palavras-chave: tradução; ética; filosofia; Wittgenstein.

\section{KNOWLEDGE AND VALUE: WITTGENSTEIN'S FIRST-PERSON ETHICS AND ITS IMPLICATIONS FOR TRANSLATION STUDIES}

In its ordinary use, the concept of ethics tends to be associated with lists of norms and general standards for social and professional practice. A different meaning can be extracted from Ludwig Wittgenstein's philosophical reflections, with significant implications for the theory and practice of translation - in regard not only to the ethical dimension, but also to the very foundations of meaning.

Keywords: translation; ethics; philosophy; Wittgenstein.

\section{TRADUÇÃO, GLOBALIZAÇÃO E TERRORISMO INTERNACIONAL: UMA LEITURA ATRAVÉS DA IMPRENSA ESPANHOLA Luis PEGENAUTE}

Estuda-se a tradução em relação com a globalização e o terrorismo internacional. Atenção especial é dedicada ao modo como a tradução é representada na imprensa espanhola.

Palavras-clave: tradução; globalização; terrorismo; imprensa espanhola.

TRADUCCIÓN, GLOBALIZACIÓN Y TERRORISMO INTERNACIONAL: UNA

$$
\text { LECTURA A TRAVÉS DE LA PRENSA ESPAÑOLA }
$$

Se estudia la traducción en relación con la globalización y el terrorismo internacional. Se presta particular atención al modo en que la traducción aparece representada en la prensa española.

Palabras-clave: traducción; globalización; terrorismo; prensa española.

\section{TRANSLATION, GLOBALISATION AND INTERNATIONAL TERRORISM: A READING THROUGH SPANISH PRESS}

Translation is studied in relation to globalisation and international terrorism. Particular attention is paid to the way translation is depicted in Spanish press.

Keywords: translation; globalization; terrorism; Spanish press.

\section{REFLEXÕES SOBRE A NOÇÃO BERMANIANA DE RELAÇÃO À LUZ DO CONCEITO DERRIDIANO DE HOSPITALIDADE \\ Simone Christina PETRY}

Este artigo discute a visada ética da tradução tal como articulada pelo teórico Antoine Berman, para quem a essência dessa prática é ser relação com o Outro. Em seguida, problematiza-se a noção de relação através do diálogo desta com o conceito derridiano de hospitalidade. Por fim, essa problematização é apresentada como uma problematização do próprio fazer tradutório, tendo em vista a discussão da noção de tradução como relação.

Palavras-chave: tradução; relação; hospitalidade; tradução como relação. 


\section{REFLECTIONS ON THE BERMANIAN NOTION OF RELATION IN THE LIGHT OF THE DERRIDEAN CONCEPT OF HOSPITALITY}

This paper discusses the ethical aim of translation in Antoine Berman's terms, which affirm as the essence of translation the relation with the Other. This Bermanian notion of relation is then discussed from the point of view of the Derridean concept of hospitality. Finally, these reflections point to a problematization of translation itself, in view of the discussion of translation as relation.

Keywords: translating; relation; hospitality; translation as relation.

\section{SIGNO, SUJEITO E TRADUÇÃO \\ Márcia Atálla PIETROLUONGO}

O presente trabalho pretende abordar, a partir de várias de suas obras, as concepções do poeta, tradutor, crítico, teórico da linguagem e ensaísta francês Henri Meschonnic sobre a tradução literária e suas implicações. Mostraremos o quanto sua teoria da linguagem, fundada numa certa ética, poética e política da tradução, pode contribuir para pensarmos a questão do signo e do sujeito no campo dos Estudos da Tradução.

Palavras-chave: Henri Meschonnic; subjetividade; tradução; teorias da linguagem; crítica do signo; ritmo.

\section{SIGN, SUBJECT AND TRANSLATION}

This article discusses the concepts and views of the French poet, translator, critic and essayist Henri Meschonnic concerning literary translation. His language theory, expounded in several works, may contribute to the understanding of the sign and subjectivity in the field of Translation Studies.

Keywords: Henri Meschonnic; subjectivity; translation; language theories; sign criticism; rhythm.

\section{PREFÁCIOS E NOTAS: DIZER, AGIR, SENTIR Cristina Carneiro RODRIGUES}

Antoine Berman, em Pour une critique des traductions (1995), sugere um caminho para análise de traduções fundamentada, entre outros elementos, nos projetos que as sustentam. Tomando como base essa proposta, neste trabalho examinam-se elementos paratextuais de traduções publicadas pela Companhia Editora Nacional entre 1930 e 1950. Como prefácios e notas constituem-se como locais privilegiados para a exposição dos projetos tradutórios, o objetivo é examiná-los, do ponto de vista ético, evidenciando que pode haver tensão entre o dizer e o agir, ou seja, pode haver conflito entre o projeto explicitado e sua execução.

Palavras-chave: Companhia Editora Nacional; História da tradução; tradutor; ética; Antoine Berman; paratexto.

\section{PREFACES AND NOTES: SAYING, DOING, FEELING}

Antoine Berman, in Pour une critique des traductions (1995), suggests a way to analyze translations grounded on the projects that support them, among other elements. Based on his proposal, in this paper paratextual elements of translations published by Companhia Editora Nacional between 1930 and 1950 are examined. Considering that prefaces and notes are privileged places to present translation projects, the purpose is 
to examine them from the ethical point of view, evidencing that there may be tension between saying and doing, that is, that there may be conflict between the project presented and its execution.

Keywords: Companhia Editora Nacional; translation history; translator; ethics; Antoine Berman; paratext.

\section{A IMPORTÂNCIA DE UMA TRADUÇÃO PARA O PORTUGUÊS DE ZUR AUFFASSUNG DER APHASIEN - EINE KRITISCHE STUDIE, DE SIGMUND FREUD \\ Emiliano de Brito ROSSI}

O presente artigo trata da importância de uma tradução para a língua portuguesa do texto inaugural de Sigmund Freud, Zur Auffassung der Aphasien - Eine kritische Studie, de 1891. Alguns dos aspectos centrais da obra, tais como conceitos psicanalíticos nela inaugurados e as disputas teóricas ali travadas, encontram-se aqui ilustrados. Se entendermos que a linguagem encontra-se nas origens da psicanálise, então esta obra é uma etapa fundamental em seu estudo.

Palavras-chave: Sigmund Freud; psicanálise; estudos da tradução; linguagem; afasia.

\section{THE IMPORTANCE OF A TRANSLATION INTO PORTUGUESE OF SIGMUND FREUD'S \\ ZUR AUFFASSUNG DER APHASIEN - EINE KRITISCHE STUDIE}

This paper discusses the importance of a translation into Portuguese of Sigmund Freud's inaugural work Zur Auffassung der Aphasien - Eine kritische Studie, written in 1891. Some of its main aspects, such as the psychoanalytical concepts that were then employed for the first time, as well as some theoretical challenges that took place within it, are here illustrated. If we think that language lies at the very origin of psychoanalysis, this book is a fundamental step in its study.

Keywords: Sigmund Freud; psychoanalysis; translation studies; language; aphasia.

\section{IMPLICAÇÕES ÉTICAS DA ADOÇÃO DE SISTEMAS DE MEMÓRIA PARA A PRÁTICA DE TRADUÇÃO \\ Érika Nogueira de Andrade STUPIELLO}

Este trabalho apresenta uma análise da questão ética que permeia as relações entre tradutor/tradução, tradutor/outros tradutores e tradutor/cliente em trabalhos parcialmente automatizados. A crescente demanda por traduções elaboradas de maneira rápida para atender a exigências mercadológicas oriundas da expansão da comunicação pela internet — tem levado tradutores a adotar ferramentas tecnológicas atualmente disponíveis, em especial, de sistemas de memórias de tradução. O emprego desses sistemas tem ocasionado mudanças significativas na concepção sobre o que envolveria o trabalho do tradutor e a extensão de sua responsabilidade pelas traduções.

Palavras-chave: tradução; ética; sistemas de memória de tradução; automatização.

\section{ETHICAL IMPLICATIONS OF THE ADOPTION OF TRANSLATION MEMORIES FOR THE TRANSLATION PRACTICE}

This paper analyzes the ethical issue permeating the relationship between translator/translation, translator/other translators and translator/client when partially 
automated translation work is carried out. The growing demand for fast translations to meet market requirements resulting from the expansion of communication through the Internet - has led translators to adopt some of the currently available technological tools, especially translation memory systems. The employment of these systems has led to significant changes in the conception of what is involved in the translator's work and the range of his/her responsibility for translations.

Keywords: translation; ethics; translation memory systems; automation.

\section{A TRADUÇÃO E SUA RELAÇÃO COM O INCONSCIENTE: TRANSMITIR A PSICANÁLISE \\ Viviane VERAS}

Afirmando-se freudiano, é muitas vezes pondo em jogo diversas formas de traduzir que Lacan leva adiante seu trabalho de transmissão: na consonância de Unbewusst com l'une-bévue, Lacan renomeia um inconsciente que se manifesta como um tropeço, uma interrupção. Neste trabalho, interessa-me discutir, a partir do livro dos chistes, da dificuldade de defini-los e de sua resistência à tradução, a questão da transmissão. Para abordá-la, a partir de uma relação entre tradução e inconsciente, ponho em diálogo uma conferência de Lacan e o albergue do longínquo de Berman.

Palavras-chave: tradução-transmissão; inconsciente; chiste; Freud; Berman; Lacan.

\section{TRANSLATION AND ITS RELATION TO THE UNCONSCIOUS: THE TRANSMISSION OF PSYCHOANALYSIS}

Proclaiming himself "a Freudian", it is often by means of different forms of translation that Lacan carries out his transmission work: in the consonance between Unbewusst and l'une-bévue, Lacan renames an unconscious that manifests itself as a stumbling, as an interruption. Drawing on Freud's book on jokes, and considering how jokes resist being defined and translated, this work discusses the issue of transmission from the perspective of the relationship between translation and the unconscious, articulating a lecture delivered by Lacan and Berman's L'auberge du lointain.

Keywords: translation-transmission; unconscious; jokes; Freud; Berman; Lacan. 